\title{
Physicians' legal duty of care and legal right to refuse to work during a pandemic
}

\author{
Cara E. Davies JD, Randi Zlotnik Shaul LLM PhD
}

Previously published at www.cmaj.ca

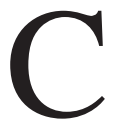
onsiderable literature exists on physicians' ethical obligations to treat during pandemics, but much less has been written about their legal obligations. Without understanding the legal landscape, physicians could face serious professional and personal consequences: those who breach their legal duties may face negligence lawsuits, and those who do not understand their legal right to refuse to work in unsafe conditions may face serious injury and even death. Globally, physicians are grappling with similar issues, although the legal implications vary in each country. Physicians working during a pandemic in Canada need to be aware of their legal rights and duties specific to the provinces in which they work.

\section{Legal duty of care}

\section{Existing patients}

Physicians have a legal duty to provide a certain standard of skill and care to their existing patients. ${ }^{1}$ The legal duty of care is created when a physician agrees to treat a patient who has requested his or her services. ${ }^{1}$ In determining what that duty requires, physicians should consider whether the care they are providing is that which a "reasonable physician" would provide under the circumstances. Specialists would need to exercise a higher degree of skill in their area of expertise. ${ }^{2}$

Legal scholars suggest that duty of care comprises several catalogued duties: attending, diagnosing, referring, treating and instructing the patient. ${ }^{1}$ If a physician breaches the duty of care and a patient experiences an injury as a result, the physician may be found guilty of negligence and forced to pay the injured patient or family monetary damages. ${ }^{3}$ Professional insurance may cover these costs. ${ }^{4}$

There is limited case law, literature and legislation on a physician's legal duty of care during a pandemic. ${ }^{5}$ Physicians can gain insight into their obligations by becoming familiar with general legal doctrines and legislation developed in nonpandemic cases. For example, physicians working during a pandemic may contemplate terminating their relationship with certain patients. However, an abrupt severance of the physician-patient relationship could result in a negligence suit if it causes injury to the patient that would have been foreseeable to a reasonable physician. ${ }^{3}$

\section{Others}

All Canadian provinces have legislation that outlines the government's powers during a state of emergency (Table 1). Such legislation permits the government to authorize or, in

\section{Key points}

- Physicians in Canada owe a legal duty of care to their existing patients and, in certain circumstances, to those who are not their patients.

- Some physicians have a legal right to refuse to work if they can satisfy the four criteria defined by labour boards in Canada.

- Ethical, professional and legal collaboration is needed to address the tensions between physicians' legal rights and duties and their ethical responsibilities.

some provinces, require physicians to provide services they are reasonably qualified to provide if a pandemic is declared a state of emergency. This legislation prevails over other legislation for the duration of the emergency. The liability of physicians acting under provincial statutes varies, but it is usually limited to that of gross negligence or acts that are committed in bad faith.

Regardless of a declared state of emergency, physicians may wonder whether they have a legal obligation to treat people who are not their patients if they require immediate emergency attention. The traditional view is that physicians owe a duty of care only to their existing patients, even in an emergency. ${ }^{1}$ There is an exception in Quebec, where legislation states that every person must come to the aid of anyone whose life is in peril, unless it would put his or her life or another's life in jeopardy. ${ }^{6}$

The courts may be willing to shift away from this traditional position. Physicians working in emergency departments or who regularly provide emergency services may be found to owe a duty of care to people who are not their patients because of the reliance the public places on these physicians to provide emergency treatment. ${ }^{7}$ These physicians may face liability if they incautiously turn away people who require emergency care during a pandemic. What will be deemed incautious will depend on the circumstances; in assessing liability, the courts will consider what a reasonable physician would have done in those circumstances.

A physician serving a rural or isolated community might also legally be precluded from turning away a person who is not his

From the Joint Centre for Bioethics (Davies, Zlotnik Shaul) and the Department of Pediatrics (Zlotnik Shaul), University of Toronto; and The Hospital for Sick Children (Zlotnik Shaul), Toronto, Ont.

CMAJ 2009. DOI:10.1503/cmaj.091628 
or her patient, at least while the condition of the individual is serious and travel to an alternative medical facility is unrealistic. ${ }^{3}$

Irrespective of a legal duty to care for someone who is not a patient, if a physician chooses to come to a person's aid during an emergency, he or she may have created a physicianpatient relationship and therefore assumed the resulting liability. ${ }^{3}$ Liability may be limited by Good Samaritan legislation, which exists in all provinces except New Brunswick. This legislation states that physicians who provide aid at the scene of an emergency and without expectation of compensation will be found liable only if they commit gross negligence.

\section{Legal right to refuse to work}

Hospitals and health care facilities in Canada are governed by the occupational health and safety statutes of each province. The provisions for the right to refuse to work because of unsafe conditions are slightly different in each province. For

Table 1: Provincial legislation for emergency management: government powers to authorize or require physicians to work during a pandemic

\begin{tabular}{|c|c|c|c|}
\hline Jurisdiction & Statute & Government powers & $\begin{array}{l}\text { Liable for action } \\
\text { under the act }\end{array}$ \\
\hline British Columbia & $\begin{array}{l}\text { Emergency } \\
\text { Program Act }\end{array}$ & $\begin{array}{l}\text { Authorize or require any person to render assistance of } \\
\text { a type that the person is qualified to provide or that } \\
\text { otherwise is or may be required to prevent, respond to } \\
\text { or alleviate the effects of an emergency or disaster. }\end{array}$ & $\begin{array}{l}\text { Bad faith or gross } \\
\text { negligence }\end{array}$ \\
\hline Alberta & $\begin{array}{l}\text { Emergency } \\
\text { Management Act }\end{array}$ & $\begin{array}{l}\text { Authorize or require any qualified person to render aid } \\
\text { of a type the person is qualified to provide. Authorize } \\
\text { the conscription of persons needed to meet an } \\
\text { emergency. }\end{array}$ & Gross negligence \\
\hline Saskatchewan & $\begin{array}{l}\text { Emergency } \\
\text { Planning Act }\end{array}$ & $\begin{array}{l}\text { Authorize any qualified person to render aid of a type } \\
\text { that the person is qualified to provide. Conscript } \\
\text { persons needed to meet an emergency. }\end{array}$ & $\begin{array}{l}\text { Bad faith or gross } \\
\text { negligence }\end{array}$ \\
\hline Manitoba & $\begin{array}{l}\text { Emergency } \\
\text { Measures Act }\end{array}$ & $\begin{array}{l}\text { Authorize or require any qualified person to render aid } \\
\text { of such type as that person may be qualified to provide. }\end{array}$ & Bad faith or negligence \\
\hline Ontario & $\begin{array}{l}\text { Emergency } \\
\text { Management } \\
\text { and Civil } \\
\text { Protection Act }\end{array}$ & $\begin{array}{l}\text { Authorize, but not require, any person, or any person of } \\
\text { a class of persons, to render services of a type that that } \\
\text { person, or a person of that class, is reasonably qualified } \\
\text { to provide. }\end{array}$ & Bad faith \\
\hline Quebec & $\begin{array}{l}\text { Civil Protection } \\
\text { Act }\end{array}$ & $\begin{array}{l}\text { Require the assistance of any person capable of assisting } \\
\text { the personnel deployed. }\end{array}$ & $\begin{array}{l}\text { Intentional or gross } \\
\text { fault }\end{array}$ \\
\hline New Brunswick & $\begin{array}{l}\text { Emergency } \\
\text { Measures Act }\end{array}$ & $\begin{array}{l}\text { Authorize or require any person to render such aid as } \\
\text { that person is competent to provide. }\end{array}$ & $\begin{array}{l}\text { Only by order of } \\
\text { Lieutenant-Governor in } \\
\text { Council }\end{array}$ \\
\hline Nova Scotia & $\begin{array}{l}\text { Emergency } \\
\text { Management Act }\end{array}$ & $\begin{array}{l}\text { Authorize or require a qualified person to render aid of } \\
\text { such type as that person may be qualified to provide. }\end{array}$ & No liability \\
\hline Prince Edward Island & $\begin{array}{l}\text { Emergency } \\
\text { Measures Act }\end{array}$ & $\begin{array}{l}\text { Authorize or require any qualified person to render } \\
\text { assistance of such type as that person may be willing } \\
\text { and qualified to perform. }\end{array}$ & $\begin{array}{l}\text { Only by order of } \\
\text { Lieutenant-Governor in } \\
\text { Council }\end{array}$ \\
\hline $\begin{array}{l}\text { Newfoundland and } \\
\text { Labrador }\end{array}$ & $\begin{array}{l}\text { Emergency } \\
\text { Services Act }\end{array}$ & $\begin{array}{l}\text { Retain persons for the purpose of responding to the } \\
\text { declared emergency whose training and qualifications } \\
\text { appear to the Lieutenant-Governor in Council, in } \\
\text { consultation with the appropriate minister, to be } \\
\text { adequate to perform medical, dental, nursing, } \\
\text { pharmaceutical, optometrical [sic], engineering and } \\
\text { other professional services. }\end{array}$ & $\begin{array}{l}\text { Bad faith or gross } \\
\text { negligence }\end{array}$ \\
\hline Yukon Territory & $\begin{array}{l}\text { Civil Emergency } \\
\text { Measures Act }\end{array}$ & $\begin{array}{l}\text { Minister may do all things considered advisable for the } \\
\text { purpose of dealing with the emergency. May do those } \\
\text { acts considered necessary for protecting the health, } \\
\text { safety and welfare of the inhabitants of the area. }\end{array}$ & No liability \\
\hline Northwest Territories & $\begin{array}{l}\text { Civil Emergency } \\
\text { Measures Act }\end{array}$ & $\begin{array}{l}\text { Authorize or require a qualified person to render aid of } \\
\text { the type that the person is qualified to provide. } \\
\text { Authorize the conscription of persons needed to meet } \\
\text { an emergency. }\end{array}$ & No liability \\
\hline Nunavut & $\begin{array}{l}\text { Civil Emergency } \\
\text { Measures Act }\end{array}$ & $\begin{array}{l}\text { Authorize or require a qualified person to render aid of } \\
\text { the type that the person is qualified to provide. } \\
\text { Authorize the conscription of persons needed to meet } \\
\text { an emergency. }\end{array}$ & No liability \\
\hline
\end{tabular}


example, in Manitoba, a worker may refuse to work or do particular work if he or she believes on reasonable grounds that it constitutes a danger to his or her safety or health or to the safety or health of another worker or person. ${ }^{8}$

During a pandemic, physicians may be faced with conditions they believe are unsafe. The right to refuse to work while unsafe conditions exist depends on the circumstances and the province in which physicians practise. If physicians have a legal right, they may stop working until the unsafe situation has been addressed without facing discipline from their superiors. Because this right exists to protect workers from discipline, physicians who are self-employed and practise from their office do not have a right to refuse to work. However, these physicians are usually employers and should be aware of their employees' right to refuse to work during a pandemic.

\section{Pandemic as a workplace hazard}

A preliminary issue is whether a pandemic virus constitutes a workplace hazard; much depends on the nature of the virus. One labour board has stated that an infectious disease might be considered a workplace hazard if the risk of contracting the virus is substantially higher in the workplace than in the community. ${ }^{9}$

\section{Criteria for justifying a refusal to work}

Labour boards across Canada have affirmed that workers must satisfy four criteria to justify a refusal to work because of unsafe or dangerous conditions: ${ }^{10}$

- Workers must honestly believe that their health or wellbeing is endangered. They cannot refuse to work for a reason unrelated to safety. ${ }^{11}$

- Workers must reasonably believe that their health or wellbeing is endangered. That is, another worker with the same training and experience would also believe that the circumstances represent an unacceptable hazard. ${ }^{12}$

- Workers must communicate their concerns to their supervisor in a reasonable and adequate manner. This usually requires workers to notify their supervisor of their refusal to work, and the reasons for their refusal, as soon as possible.

- The danger must be sufficiently serious to justify the action; it must be immediate ${ }^{13}$ and more than a matter of repugnancy, unpleasantness or fear of minor injury. ${ }^{14}$

\section{Increased susceptibility to infection}

During a pandemic, certain populations will emerge for whom the virus will pose a particularly grave risk. When a physician with a susceptibility to infection is justifying a refusal to work, he or she should consider the four criteria outlined earlier.

Employers have a duty under human rights law to try to accommodate workers with particular susceptibilities. ${ }^{15}$ An employer who refuses may be found to be discriminating on the basis of sex (when pregnancy is the source of susceptibility) or disability (when an underlying medical condition is the source of susceptibility). What is considered sufficient accommodation depends on each case. Human rights law requires accommodation to the point of undue hardship - that is, employers must be willing to endure some degree of hardship, ${ }^{16}$ such as creating a new position or displacing another worker. ${ }^{17}$

\section{Limits to the right to refuse work}

\section{Acceptable hazard}

Physicians will be permitted to refuse to practise only if they reasonably believe that the work environment creates an unacceptable hazard. Policy-makers and labour boards suggest two types of acceptable hazard: those that are inherent to the occupation of the worker and those that are part of the normal working conditions. ${ }^{14}$ The occupational health and safety statutes of Alberta, Ontario, Quebec, Nova Scotia, Yukon Territory, Northwest Territories, Nunavut and the federal government explicitly state that workers may not refuse to work when the hazard falls within these two categories. In provinces where the legislation is not explicit, labour boards have sometimes interpreted the legislation as if it contained these limits. ${ }^{15}$

A commonly used analogy serves to illustrate the difference between acceptable and unacceptable hazards. ${ }^{18}$ A firefighter likely would be unable to refuse to enter a burning building simply because the building is on fire. Entering a burning building is dangerous, but it is inherent to the work. It is also likely that the firefighter would be unable to refuse to enter a burning building with safety equipment that is used by all firefighters. The use of such equipment is a normal working condition that has been established as sufficiently safe.

Similarly, it is unlikely that physicians will be able to refuse to work because of dangers inherent to their job. ${ }^{14}$ When physicians join the health care profession, they implicitly accept a level of risk associated with the profession. To determine whether a specific practice is inherent to the work, physicians might ask themselves, "If I remove what is claimed to be inherent, does my job continue to exist?"19 The answer will depend on the job and the individual.

It is equally unlikely that physicians will be able to refuse work that is part of their normal working conditions. ${ }^{14}$ Normal working conditions tend to be questioned only when the standard safety equipment is malfunctioning ${ }^{18}$ or the existing and established practice in the new circumstance creates an imminent danger or risk. ${ }^{20}$

Only provincial and federal legislation that is aimed at protecting the health of workers will likely be viewed as establishing acceptable health and safety standards. ${ }^{21}$ Hazards that remain after these standards have been followed will likely be viewed as normal working conditions. Physicians would probably have to show a substantial change in circumstances to illustrate that the once acceptable safety standards now create a danger. ${ }^{22}$

\section{Refusal endangering another person}

The occupational health and safety statutes of Ontario, Quebec, Nova Scotia, Yukon Territory and the federal government state that workers may not refuse to work if such refusal puts the life, health or safety of another person in danger. There is no evidence that this limit will be applied in the provinces whose occupational health and safety statutes do not contain this limit.

The cases where this limit will apply will depend on the person's circumstances. For example, physicians who work in large health care facilities where someone else can easily assume their responsibilities might not be viewed as endangering a patient or 
another physician in the event of a refusal to work. ${ }^{23}$ However, a physician who works in a remote community and is the only person capable of performing certain essential tasks might be seen as endangering others if he or she refuses to work.

\section{Ethical duty of care and legal implications}

As members of a self-regulated profession, physicians have ethical responsibilities to their patients, to society, to the profession and to themselves. These responsibilities are codified in the Canadian Medical Association Code of Ethics. ${ }^{24}$ Anyone concerned about a physician breaching the Code of Ethics can lodge a complaint with the College of Physicians and Surgeons in the province in which the physician is registered or licensed. ${ }^{25}$ If a breach has occurred, the physician may be found guilty of professional misconduct and can be fined or have his or her medical licence revoked. ${ }^{26}$

During a pandemic, physicians may experience tension between their ethical responsibilities and their legal rights and duties. For example, the Code of Ethics states that physicians have a fundamental ethical responsibility to "consider first the well-being of the patient" but also to "promote and maintain [their] own health and well-being." ${ }^{24}$ Some colleges have outlined ethical dilemmas that may occur during a pandemic and have produced policy statements specific to physicians' ethical obligations. ${ }^{27-29}$ The issues become more complicated when one considers physicians' legal duty of care and their legal right to refuse to work in unsafe conditions. Physicians need to know that the existence of this separate regulatory regime does not negate their right to refuse to work in unsafe conditions, nor does it shield them from negligence liability for a breach of their legal duty of care.

\section{Conclusion}

Because of the legal uncertainty surrounding physicians' rights and obligations during a pandemic, physicians should not rely unrealistically on existing legislation or case law. We cannot deceive ourselves into thinking that physicians have absolute autonomy with respect to the work they choose to do or that they can be forced to work under any circumstances. Physicians need to remain aware of evolving legal developments and ethical discourse. The nature of rights and obligations in various contexts will be informed by ethical, professional and legal collaboration. Physicians need to work with health care institutions, regulatory bodies and the public to ensure that those working during a pandemic feel safe and willing to work.

This article has been peer reviewed.

Competing interests: None declared.

Contributors: Cara Davies was responsible for most of the research and drafting, and Randi Zlotnik Shaul provided substantial revisions on the intellectual content. Both authors contributed substantially to the conception and design of the manuscript and the interpretation of the law reviewed. Both read and approved the final version submitted for publication.

Acknowledgements: The authors thank Ross Upshur and the team from the Canadian Program of Research on Ethics in a Pandemic (CanPREP) for providing invaluable guidance on this paper.
Funding: The authors are supported by a CanPREP grant from the Canadian Institutes of Health Research.

Note: This paper provides information on the law that presided at the time of its publication. The information is not intended to provide legal advice to any individual or entity. Readers should consult with a legal advisor before taking any action based on information provided in this paper.

\section{REFERENCES}

1. Picard EI, Robertson GB. Legal liability of physicians and hospitals in Canada. 4th ed. Toronto (ON): Thomson Carswell; 2007.

2. Crits v. Sylvester, [1956] OR 132, aff'd [1956] SCR 991.

3. Sneiderman B, Irvine JC, Osborne PH. Canadian medical law: an introduction for physicians, nurses and other health care professionals. 3rd ed. Scarborough (ON): Carswell; 2003.

4. Canadian Medical Protective Association. Services: legal assistance. Ottawa (ON): The Association; 2008. Available: www.cmpa-acpm.ca/cmpapd04/docs/about _cmpa/com_services-e.cfm. (accessed 2009 Aug. 17)

5. Schwartz AR. Doubtful duty: physicians' legal obligation to treat during an epidemic. Stan L Rev 2007:60:657-94.

6. Charter of Human Rights and Freedoms, RSQ c C-12, s2.

7. Barnett v. Chelsea \& Kensington Hospital Management Committee, [1969] 1 QB 428.

8. Workplace Safety and Health Act, CCSM c W210, s43 (1).

9. Review decision [review reference no. R0051037]. Vancouver (BC): WorkSafe BC; 2005. Available: www.worksafebc.com/review_search/decisions/compensation _decisions/r0051037_decision_letter.pdf (accessed 2009 Aug. 18).

10. Re Steel Co. of Canada Ltd. and U.S. W., Loc. 1005. (1973) 4 LAC (2d) 315 (Ontario Labour Arbitration).

11. Douglas and Canadian Corps of Commissionaires (Hamilton), [1995] OLRD No 1952.

12. Pharand and Inco Metals Co, [1980] OLRB Rep 981.

13. Janes (Re) [1999] CIRB No 38. Re: Appeal Division Reference \# 2002-2608 (2002 Oct 8).

14. Brown DJM, Beatty DM. Canadian labour arbitration. Vol. 2. 4th ed. Aurora (ON): Canada Law Book; 2009.

15. British Columbia Public School Employers' Assn. v. British Columbia Teachers Federation, (2006) 147 LAC (4th) 251 (British Columbia Collective Agreement Arbitration)

16. Central Okanagan School District No. 23 v. Renaud. 19922 SCR 970, aff'd in British Columbia (Public Service Employee Relations Commission) v. British Columbia Government and Service Employees' Union (B.C.G.S.E.U.) (Meiorin), [1999] 3 SCR 3.

17. Dominion Colour Corporation and Teamsters, (1999) 83 LAC (4th) 330 (Ontario Arbitration Board)

18. Maplehurst Detention Centre: Ontario Public Service Employees Union, Local 234 (Re), [1994] OOHSAD No 21.

19. Canadian Union of Public Employees, Its Local 1605, and Mohawk Hospital Services Inc., and Ministry of Labour, [1993] OOHSAD No 20

20. Applicant v. Ministry of Labour and Ministry of Solicitor General and Correctional Services (Whitby Jail), Responding Parties [1998] OOHSAD No 201.

21. Abarquez v. Ontario, 2009 ONCA 374, 95 OR (3d) 414, leave to appeal to SCC requested, Docket 33263 (2009 Aug. 4).

22. Decision review [review reference no. R0091984]. Vancouver (BC): British Columbia: WorkSafe BC; 2007. Available: www.worksafebc.com/review_search /decisions/prevention_decisions/r0091984_decision_letter_prev.pdf (accessed 2009 Aug. 18).

23. OPSEU Local 359, OPSEU Local 608, Applicants v. Ministry of Solicitor General and Correctional Services and Ministry of Labour, Responding Parties, [1997] OOHSAD No 319 (OLRB).

24. Canadian Medical Association. CMA code of ethics: update 2004. Ottawa (ON): The Association; 2004. Available: http://policybase.cma.ca/PolicyPDF/PD04-06 .pdf (accessed 2009 Aug. 18).

25. Canadian Medical Association. Frequently asked questions. Are you looking for a doctor, or do you wish to file a complaint about a physician? Ottawa (ON): The Association; 2009. Available: www.cma.ca/index.cfm/ci_id/25297/la_id/1.htm\#8 (accessed 2009 Sept. 2).

26. Regulated Health Professions Act, 1991, SO 1991, c 18, Sched 2, s51(2).

27. College of Physicians and Surgeons of Newfoundland and Labrador. Guideline on health emergencies. St. John's (NL): The College; 2009. Available: www.nmb.ca /NewsList.asp?ID=46. (accessed 2009 Nov. 17).

28. College of Physicians and Surgeons of Nova Scotia. Physician scope of practice in a health emergency or pandemic. Halifax (NS): The College; 2009. Available: www.cpsns.ns.ca/whatsNew.html (accessed 2009 Nov. 17).

29. College of Physicians and Surgeons of Ontario. Physicians and health emergencie (policy statement no. 2-09). Toronto (ON): The College; 2009. Available: www.cpso.on.ca/policies/policies/default.aspx?id=3510 (accessed 2009 Nov. 17).

Correspondence to: Cara E. Davies, 26 Oriole Cres., Toronto ON

M5P1L5; cara.davies@utoronto.ca 